\title{
Terminal Lucidity in People with Mental Illness and Other Mental Disability: An Overview and Implications for Possible Explanatory Models
}

\author{
Michael Nahm, Ph.D. \\ Freiburg, Germany
}

\begin{abstract}
The literature concerned with experiences of the dying contains numerous accounts reporting the sudden return of mental clarity shortly before death. These experiences can be described as Terminal Lucidity (TL). The most peculiar cases concern patients suffering from mental disability including mental illness or dementia. Despite the potential relevance of TL for developing new forms of therapies and for elaborating an improved understanding of the nature of human consciousness, very little has been published on this subject. In this paper I present a historical overview and selected case reports of TL of mentally ill or otherwise disabled patients, mainly drawing on the literature available in English and in German. Possible explanatory models of TL and their implications are discussed.
\end{abstract}

KEY WORDS: Terminal lucidity; end-of-life experience; mental illness; mental disability; human consciousness.

Since Raymond Moody's (1975) classical publication, near-death experiences (NDEs) have received much attention. Academics and professionals continue to discuss them because of their potentially

Michael Nahm, Ph.D., is a biologist. After conducting research in the field of tree physiology for several years, he is presently concerned with developing improved strategies for harvesting woody plants for energetic use. He has a long-standing interest in unsolved problems of evolution and their possible relation to unsolved riddles of the mind and has published a book on these subjects (Evolution und Parapsychologie, 2007). Reprint requests should be addressed to Dr. Nahm at Ida-Kerkovius-Straße 9, 79100 Freiburg, Germany; e-mail: michaelnahm@web.de. 
enormous importance for a better understanding of the dying process and the nature of human consciousness (e.g., Holden, Greyson, \& James, 2009; Kelly, Kelly, Crabtree, Gauld, Grosso, \& Greyson, 2007; Parnia, 2007).

Yet, a number of other remarkable experiences and phenomena related to dying have received far less attention. According to those who observe or experience them, they occur shortly before, at, or shortly after the moment of the cessation of vital body functions. They are specifically characterized in that the patients do usually not revive. These phenomena can be summarized as end-of-life experiences (ELEs; Fenwick, Lovelace, \& Brayne, 2007). Below I present a short introductory list of notable ELEs. To allow for a deeper study of this largely neglected field of research, I add references to essential publications describing their occurrence. Other authors have been concerned mainly with the interpretation of specific ELEs (e.g., Betty, 2006; Houran \& Lange, 1997), but in the present paper I will not enter this discussion.

Among others, ELEs include the following kinds of frequently interrelated experiences:

- deathbed visions: having visions of deceased relatives, friends or religious figures, and often communicating with them (Barbato, Blunden, Reid, Irwin, \& Rodriguez, 1999; Barrett, 1926; Becker, 1985; Bozzano, 1906; Brayne, Lovelace, \& Fenwick, 2008; Fenwick \& Fenwick, 2008; Giovetti, 1982, 1999; Kelly, Greyson, \& Kelly, 2007; Osis, 1961; Osis \& Haraldsson, 1977, 1997)

- seemingly veridical spatial clairvoyance and correct future predictions related by the dying (Barrett, 1926; Bozzano, 1906; Brierre de Boismont, 1855/2003; Callanan \& Kelley, 1997; du Prel, 1888/1971; Roesermueller, 1957; Splittgerber, 1881)

- telepathic impressions or apparitions of the dying person at the moment of death, experienced by close relatives or friends not present at the bedside of the dying person (Fenwick \& Fenwick, 2008; Flammarion, 1922; Gurney, Myers, \& Podmore, 1886; Roesermueller, 1957; Stevenson, 1995; Wright, 1999)

- synchronistic acoustic or physical phenomena such as knocking sounds, hearing music, moving of doors, falling and breaking of objects, odd behavior of electrical devices, and stopping of clocks (Alvarado, 2006, 2007; Barrett, 1926; Bozzano, 1943/1982; Brayne, Lovelace, \& Fenwick, 2008; Martensen-Larsen, ca. 1926; Fenwick \& Fenwick, 2008; Flammarion, 1922; O’Connor, 
2003; Rhine, 1963; Rogo, 1970/2005a, 1972/2005b; Splittgerber, 1881)

- emanations of mists, shapes, lights or a radiance from dying persons (Alvarado, 2006; Crookall, 1967; Fenwick, Lovelace, \& Brayne, 2007; Fenwick \& Fenwick, 2008; Martensen-Larsen, ca. 1927; Roesermueller, 1957; O'Connor, 2003)

- the ability to perform bodily movements or skills shortly before death which seemed impossible before (Barrett, 1926; Brayne, Lovelace, \& Fenwick, 2008; Kelly, Greyson, \& Kelly, 2007; O’Connor, 2003; Ringger, 1958; Schubert, 1808/1967)

- the (re-) emergence of normal or unusually enhanced mental abilities in dull, unconscious, or mentally ill patients shortly before death, including considerable elevation of mood and spiritual affectation, or the ability to speak in a previously unusual spiritualized and elated manner.

In this paper, I focus on presenting an overview of the latter category of ELEs. Specifically, I concentrate on cases pertaining to patients with mental disorders and include a number of case reports. Mainstream scientists, but also researchers concerned with dying as well as parapsychologists, are slow to recognize the importance of such cases (for exceptions see Brayne, Lovelace, \& Fenwick, 2008; Fenwick, Lovelace, \& Brayne, 2009; Kelly, Greyson, \& Kelly, 2007; Osis, 1961; Osis \& Haraldsson, 1997). Yet, as I hope to show in this paper, these cases hold the potential to contribute to an enhanced understanding of the nature of human consciousness and, perhaps, to the development of new forms of therapies - if only after careful future studies and collection of further well-documented case reports.

Throughout this paper, I will refer to these experiences as Terminal Lucidity (TL). Up to now, I found 80 references to TL cases in patients considered mentally ill that 50 different authors, mostly psychiatrists and physicians, had reported. Of these 80 case references, I was able to track down 49 case reports, often the original publication. Most of them stem from German and English literature of the $19^{\text {th }}$ century. Additionally, I found 14 general statements of psychiatrists, physicians, or carers who reported that they have observed TL in several people with mental illness - but unfortunately, without giving concrete case reports. It can be assumed that more TL reports of people with mental illness are on account, specifically in the French literature. It appears that TL in people with mental illness is not as uncommon as one might expect. 


\section{Historical Overview of TL in People with Mental Illness and Selected Case Reports}

Hippocrates, Plutarch, Cicero, Galen, Avicenna, and other scholars of classical times noted that symptoms of mental disorders decrease as death approaches (du Prel, 1888/1971). All of them held the view that the soul remains basically intact when the brain is affected by physical malfunction and disturbance of the mind. Therefore, they believed that during and after death, the soul was freed from material constraints, regaining its full potential. Much later in Germany during the Age of Romanticism (1785-1840), many authors, dissatisfied with the development of the Age of Enlightenment (1720-1800), reemphasized the "night side of nature." They contended that numerous phenomena including human consciousness could not be explained by quantitative mechanistic science. Thus, several treatises discussing the mysteries of dreaming, somnambulism and animal magnetism, clairvoyance, prophecies, or dying were published. The aim of these writers was usually to show that the soul is more than a by-product of brain chemistry, a notion gaining increasing importance among scientists at that time.

In the romantic context of nature philosophy and dying, the publications of physician and philosopher Gotthilf Heinrich Schubert (1780-1860) were specifically influential and also covered the topic of TL. Among others, Schubert (1808/1967) reported a case of a deafmute man and a case of a previously nonresponsive patient. In these and other cases in which I found original sources only in German, I provide an English translation:

The deaf-mute man was educated in a special school for deaf-mute persons, but still never managed to speak understandably because of an "organic defect" (not specified by Schubert). Yet, "in the elation of the last hours", he was able to speak comprehensively for the first time in his life (p. 354).

A sick old man had lied "debilitated and entirely speechless" in his bed for 28 years. On the last day of his life, his awareness and ability to speak suddenly returned after he had a joyful dream in which the end of his suffering was announced (p. 354).

In regard to mental illness, Schubert (1814/1968) stated that it sometimes ceases before death like a bad dream the individual remembers. Even more, it seemed to Schubert that in some cases the mental illness of waking life enabled the hidden development of higher aspects of the soul on deeper levels, so that individuals with mental illness who recover before death can display an extraordinary change 
and ennoblement in their thinking and speech. He reported the case of a woman who died at the age of 47 :

Four weeks before her death, she finally recovered from her bad dream that had lasted for 20 years. But those who knew her before her madness hardly recognized her in her last state of transformation - so ennobled, enhanced, and elevated were all powers and sensations of her mental nature, so ennobled her articulation. She spoke with distinctness and inner brightness about things, which man learns only rarely to understand superficially in his ordinary state of being. Her story aroused furore. Literate and illiterate, educated and uneducated crowded at this dignified sickbed. All had to confess that even if she would have been taught by the most learned and enlightened men during the time of her illness, her mind could not have been more educated, her knowledge could not have been more substantial and higher than now, as she seemed to awaken from a long and deep confinement of all powers. (p. 146)

Antedating several subsequent theories of the human mind, Schubert (1814/1968) attributed such faculties to an usually hidden "inner person" as opposed to the "outer person" constituting the familiar conscious ego. Among later German publications of the $19^{\text {th }}$ century concerned with death and dying, Schubert's influence is particularly apparent in a largely forgotten, but still intriguing, case collection of ELEs and NDEs: Franz Splittgerber's (1881) two volume treatise on "Sleep and Death." Here, Splittgerber set out to convince the reader of the transcendental nature of the soul from a Christian perspective. In the second volume of this treatise, the one concerned with dying and death, as well as in another book (Splittgerber, 1884), he recounted case reports containing virtually all kinds of ELEs featured in the introductory list of this paper. Moreover, he renarrated case reports of ostensible NDEs that contain many features familiar since recent studies almost a century later (Moody, 1975). These include:

- Veridical knowledge of the near-death experiencer (NDEr) about what was happening around the apparently dead corpse during the time of bodily unconsciousness. Yet, Splittgerber gave no explicit references regarding out-of-body experiences (OBEs).

- Travelling through darkness towards a light.

- Experiencing a detailed review of the NDEr's whole life within a very short time. Splittgerber already used the term "panoramic overview," adopting it from the NDE report of British Navy Admiral Francis Beaufort who had nearly drowned.

- Unexplained healing after reviving from states of apparent death. 
In regard to the stopping of clocks at the moment of death, Splittgerber (1881) stated that it has been reported so often that it cannot be considered a mere fiction.

Shortly after Splittgerber, philosopher Carl du Prel (1839-1899) published writings of importance for the development of early German parapsychology and the spiritistic movement. Following Schubert in drawing largely on the literature on dreaming, somnambulism, hypnotism, apparitions, but also on mediumship, du Prel (1885/1976, 1888/1971) developed a philosophical system that centered on analyses of the nature and functioning of the human consciousness. For him, the human soul consisted in the main of a subconscious but still individual "transcendental subject" whose foundations are not destroyed by bodily illness or death. He thought that the conscious self, constrained by physical matter, time, and space, constitutes only a small part of this transcendental subject whose abilities far exceed those of the conscious self. Du Prel assumed that during TL, the self begins to loosen from physical matter, thus being able to increasingly enter the usually hidden realms of the transcendental subject. His model bears numerous similarities with the concept of the "subliminal self" proposed around the same time by Frederic Myers, who also commented briefly on TL (1892, p. 316). To underline his reasoning, du Prel wrote about the experiences of life reviews near death (du Prel, 1885/1976), about apparitions and physical phenomena at or after the time of death, and about TL (1888/1971, 1889/2006). Here, he focused on those of persons with mental illness, giving many examples and references from the German literature.

Yet, it was not only authors sympathizing with Romanticism, Christian theology, philosophy, or spiritism who recognized TL in persons with mental illness. Early physicians and psychiatrists such as Benjamin Rush, author of the first American treatise on mental illness, also recognized them. Rush wrote that "most of mad people discover a greater or less degree of reason in the last days or hours of their lives" (1812, p. 257). In Britain, Andrew Marshal (1815) published a number of cases of TL in persons with mental illness, including a report of

a mad and very violent ex-lieutenant of the Royal Navy, who also suffered from severe memory loss to the extent he did not even remember his own first name. On the day before his death, he became rational and asked for a clergyman. With him, the patient conversed attentively and expressed his hope that God would have mercy on his soul. An autopsy revealed that his cranium was filled with a straw- 
coloured water to a degree that it widened parts of the brain, whereas the brain matter itself and the origin of the nerves were uncommonly firm, the olfactory nerves displaying an almost fibrose appearance (p. 150).

In France, prominent physician Alexandre Brierre de Boismont (1885/2003) observed that

in certain diseases, the senses acquire an extraordinary delicacy on the approach of death, when the sick person astonishes those about him by the elevation of his thoughts, and the sudden lucidity of a mind which has been obscured during many long years. (p. 243)

Brierre de Boismont (1855/2003) held the traditional dualistic view. However, subsequent French psychiatrists who reported other incidents of TL in people with mental illness tried to explain them in brain physiological terms (Flournoy, 1903).

In Germany, physiologist and anatomist Karl Friedrich Burdach (1826) assumed the dualistic position. He referred to several cases of TL in people with mental illness, primarily focusing on the anatomy of the deceased patients' brains. The cases he cited involved effusions of blood within the brain, fillings of the brain with abnormally colored cerebrospinal fluid, suppurations, hypertrophy, rigidification or softening of certain brain regions, and tumors.

Furthermore, Burdach (1826) stated that in fact TL can manifest two ways. First, the mental clarity can improve gradually in opposition to the gradual decline of bodily vitality. Second, the mental clarity can reappear abruptly and unexpectedly shortly before death.

Some years later, physician Johannes Baptist Friedreich (1839) recounted several case reports of TL in people with mental illness and proposed a brain physiological explanation. He argued that, similar to cases in which the amount of water had obviously been reduced in hydrocephalus patients shortly before their death, possible brain dysfunctions or contaminations leading to the mental illness must have regressed or been reabsorbed before death in these cases. In his opinion, the generation of high fever was a means by which this effect might be accomplished. Nevertheless, by this time TL cases had already been published that did not involve high fever and that sometimes did involve considerably degenerated brain tissue.

Friedreich (1839) also stated that deaf persons and persons bereft of other senses sometimes regain their ability to hear or to use their previously lost senses in the last moments of their lives - but he did not provide examples or references. Despite their dubiousness, such 
claims are noteworthy and deserve consideration. At least, similar claims have been fairly well substantiated in a closely related context, the NDEs of the blind (Ring \& Cooper, 1999).

However, despite appreciable interest during the $19^{\text {th }}$ century in TL of persons with mental illness, $20^{\text {th }}$ century mainstream scientists have practically ignored the phenomenon - perhaps assuming the problem was solved when, in fact, it had not yet been truly examined. But also parapsychologists and researchers concerned with dying and NDEs neglected TL. Even in most of the literature on ELEs cited in the introductory list, authors mentioned TL only casually because they often go hand in hand with other ELEs of dull or disoriented patients, particularly with deathbed visions. More specifically, authors mentioned TL of patients with mental illness only a few times, usually in short sketches (Brayne, Lovelace, \& Fenwick, 2008; Grosso, 2004; Kelly, Greyson, \& Kelly, 2007; Osis, 1961; Osis \& Haraldsson, 1997). In one study, several members of a palliative care team stated they have observed that patients who had been in a deep coma suddenly became alert enough to coherently say goodbye to loved ones at their bedside before they died (Fenwick, Lovelace, \& Brayne, 2009). But only in one professional medical publication of the $20^{\text {th }}$ century did authors discuss in detail TL cases. These reports concerned three people with long-term chronic schizophrenia whose mental functioning became almost normal before their deaths (Turetskaia \& Romanenko, 1975).

In Germany, moderate interest in TL of people with mental illness continued outside the academic setting of mainstream science and parapsychology throughout the $20^{\text {th }}$ century. The few respective accounts were published in sources difficult to obtain and not well known (e.g., Ringger, 1958; Roesermueller, 1957; Schiebeler, 1988; Surya, 1921). Likewise, the first two books of Danish vicar Hans Martensen-Larsen's (ca. 1926, ca. 1927, ca. 1928) trilogy on dying and the afterlife constitute a largely forgotten but valuable case collection of unusual experiences in near-death states. His books were translated into German soon after their original publication in Denmark. Here the author described the full spectrum of ELEs as Splittgerber $(1881,1884)$ had previously reported, including accounts of TL of persons with mental illness and also of NDEs.

The latter authors followed the tradition of the ancient Greeks and Romans, Schubert, Splittgerber, or du Prel, and aimed at showing that the human soul is not a mere product of brain chemistry but is an 
entity whose transcendental faculties are released at the approach of bodily death. Below, I summarize four reports of TL that Surya, Martensen-Larsen, and Ringger collected.

G. W. Surya (1921) recounted an account handed to him by a friend of his. This friend had a brother living in an asylum for many years because of serious mental derangement.

One day, Surya's friend received a telegram from the director of the asylum saying that his brother wanted to speak to him. He immediately visited his brother and was astonished to find him in a perfectly normal mental state. On leaving again, the director of the asylum decently informed the visitor that his brother's mental clarity is an almost certain sign of his approaching death. Indeed, the patient died within a short time. Subsequently, an autopsy of the brain was performed, to which Surya's friend was allowed to attend. It revealed that the brain was entirely suppurated and that this condition must have been present for a long time. Surya asks: "With what, then, did this brainsick person think intelligibly again during the last days of his life?" (p. 14)

Martensen-Larsen (ca. 1926) reported the case of a farmer's wife who was seemingly imbecile for eight years. Similar to Marshal's (1815) previously mentioned case, this account gives an example of a mental illness that, during TL, the affected person remembered as a "bad dream" and that is reminiscent of the possession by an alien will that quit the scene at the approach of its host's death.

Usually, the woman just stared in front of her; and - if at all uttered only detestable swear words. When visited by the doctor or the priest, she displayed an odd virtuosity in successfully spitting on their shoes. One day, she began to converse rationally with her caretaker and apologized from deep within her heart for her bad behaviour. Broken and remorseful, she affirmed she was not able to behave in any other way since she had been forced to act like this. It was her utmost concern whether she would be forgiven for these and other sins. When the priest arrived, he handed her the requested Lord's Supper. The next morning, she died in peace. (MartensenLarsen, ca. 1926, p. 128)

In 1958, Peter Ringger commented on du Prel's work on TL and republished an essay by minister Friedrich Happich, originally written in 1934 (Ringger, 1958). At that time, Happich had been the director of an asylum for 21 years. In his essay, he criticized the attitude that people with mental illness or mental disability should be regarded as inferior or even unworthy of living - an attitude that was particularly promoted by the German Nazis in those days. Drawing 
from his experience, Happich was sure that there exists a "hidden inner life" under the mental surface of even the most disabled imbeciles. Sometimes, parts of this hidden inner life would be displayed at the moment of death. Out of the "numerous experiences" that he allegedly encountered in this regard, Happich presented two cases. Apart from a brief mention of one other case (Perty, 1861), they seem to constitute the only cases available of TL in people with mental disability. Thus, I present them both.

Georg lived for 14 years in Happich's asylum. He arrived as a boy of six years and spoke only in ruptured curses. Confronted with the slightest obstacles, he bit himself and hit his head sore against walls and tables. It was hopeless to teach him even the easiest activities. For hours, he would sit on the same spot, rocking his body, talking to himself: "Eat soup, eat meat, eat vegetables, eat vegetables!" Later, caretakers discovered that Georg loved to sing songs and that he memorized them quite well. So, he learned many. Yet, it appeared as if he didn't understand the meaning of them. Georg could not even tell the names of the carers who taught him the songs. Whenever asked for their names, he addressed the different carers by the names of the songs which they had taught him. One day, Georg fell sick with the flu and was transferred to the hospital of the asylum, which he already knew from numerous previous occasions. Yet, contrary to the former times, he instantly started to sing songs obviously related to dying. On his way to the hospital, he sang "Though I wandered through the dark valley, I do not fear any harm." When laid down in a hospital bed, he sang all verses of the Christian dying song "O world, I have to leave you, I pass over my streets to the eternal fatherland." On the next morning, his first words were "Georg goes to heaven today." After a carer asked him to sing another song, he sang a song about a mill. As he reached the phrase “... and the millwheel didn't turn anymore", he shook hands with everybody present, said "Good night!" - and died. (Ringger, 1958, p. 217-219)

Happich wondered how Georg was able to relate these songs to his current situation, indicating that he understood their meaning this time. Additionally, I wonder how Georg could have developed an appropriate conception of death at all, let alone its confident and correct anticipation. For those who question whether it is possible to converse until the end and then expire with a farewell, in some cases this phenomenon indeed seems to be possible. Among several other authors, William Barrett (1926) gave similar accounts, including one of a professional singer who sang until she died. According to her husband, her voice "had never been so exquisitely beautiful as when she sang just before her death" (p. 104). Happich's second account also involves singing. 
One of the most disabled patients of Happich's asylum was Käthe. From birth on, she was seriously retarded and never learned to speak a single word. She could only utter animal-like voices; her bodily abilities did not exceed uncontrolled spasms. It never seemed that she took notice of what was happening around her even for a second. One day, Happich was called to immediately visit Käthe by a physician and psychiatrist of the asylum, Dr. Wittweber. Käthe was ill with tuberculosis and she was about to die. When entering the room, Happich was stunned. He continues: "We did not believe our eyes and ears. Käthe, who never spoke one word, entirely mentally disabled from birth on, sang the dying songs to herself. Specifically, she sang 'Where does the soul find its home, its peace? Peace, peace, heavenly peace!' over and over again. For half an hour she sang. Then, she quietly died. Her face, up to then so stultified, was transfigured and spiritualized. Like myself and the present nurse, the physician had tears in his eyes. He stated repeatedly: 'I cannot explain this in medical terms. If demanded, I can prove by autopsy that ... from an anatomical perspective, thinking could not have been possible.'" (Ringger, 1958, p. 219-220)

Dr. Wittweber's comments on Käthe's case were also reported elsewhere:

"I hurried to her room to observe what would contradict all medical experience. But it is true: Käthe sang, very intelligibly: 'Where does the soul find its home, its peace?' A smile caressed her stultified face, the soul flung off restraints." (Roesermueller, 1957, p. 24)

As a final case report of TL, I present an account given by famous biologist and philosopher Hans Driesch (1867-1941), describing the death of his mother who suffered from peritonitis. Though his mother was only confused but not mentally ill before her death, I include the case because it exemplifies that in some instances, ELEs such as TL are closely interrelated with NDEs - thus indicating that their phenomenologies share a common origin (similar examples are given in Barrett, 1926, and Fenwick \& Fenwick, 2008). In his autobiography, Driesch (1951) recalled what had happened after his mother went unconscious on her last day:

When we all expected that she would never wake up again and die in her sleep, something very strange happened: After having uttered only unintelligible words in the past hours, she suddenly awoke and became brightly aware, but at the same time she was very unwilling to find herself in life again! It had been so wonderful to be united with my father, her parents, and friends - all of whom were dead. In this respect one might be reminded of certain reports of Bozzano. The 
period of being awake did not last for long. Soon, my dear mother fell asleep once more, never to wake up again. (p. 40)

\section{Exploring Foundations and Implications of Explanatory Models for TL}

It is obvious that the presented anecdotal case reports do not match scientific standards. They lack numerous important information points, especially concerning the medical history of the patients and their diagnoses as well as a proper documentation of the incidents including witness testimonies. Thus, it is important to consider that particularly the more dramatic TL accounts might be embellishments of more ordinary incidents of TL. On the other hand, it is unwarranted to dismiss the possibility that these cases are simply veridical reports of what had happened. The history of science is full of examples in which important observations and theories were dismissed as "impossible" or "misinterpreted" only because of obsolete prejudice. Thus, aiming at avoiding the old mistakes and at exploring possible explanatory models for TL that comprise the full spectrum of reported cases, I will include all presented examples in this discussion. Moreover, I would like to stress that the question whether such cases like Käthe's can occur or not will not be resolved by theoretical discussions. Similar to the controversial reports of ostensibly veridical perception during NDEs and other kinds of ELEs suggestive of paranormality, only further research will provide the necessary data to support a firmer conclusion.

In regard to explanatory models, two options exist:

1) All cases of TL can be explained entirely by brain physiological processes.

2) Not all cases of TL can be explained entirely by brain physiological processes.

The first option needs to be proposed under the current materialistic paradigm of neuropsychiatry. In this model, the assumption is that the brain physiology of patients with mental illness who experience TL is altered only slightly during the illness and can be restored shortly before death - perhaps, due to a kind of psychological or bodily panic reaction following the realization of entering the terminal stage of 
living. Indeed, the fine structure of the brain tissue of patients diagnosed with schizophrenia is only slightly altered. Thus, TL in persons with schizophrenia (Osis, 1961; Turetskaia \& Romanenko, 1975), but also the TL of the old man awakening after 28 years (Schubert, 1808/1967) and that of the woman who remembered being ill (Martensen-Larsen, ca. 1926), might well be explained in this way.

Yet, this model becomes increasingly problematic in the case of a terminal meningitis patient that Karlis Osis and Erlendur Haraldsson (1997) reported, the case reports that Surya (1921) gave, and the dementia cases that Marshal (1815), Brayne, Lovelace, and Fenwick (2008), Osis (1961), and Michael Grosso (2004) presented. The latter cases concerned patients who did not recognize family members until they became lucid shortly before their death. It is known that different forms of dementia, notably Alzheimer's disease, are caused largely by degeneration and irreversible degradation of the cerebral cortex and the hippocampus, resulting among other symptoms in confusion, disorientation, and short-term and long-term memory loss (Wenk, 2003). In regard to TL, it must be assumed under the materialistic paradigm that the lost memories are not entirely deleted in dementia but are still stored somewhere in the degenerated brain tissue and are accessible again just before death. According to what is currently known about the neuropathology leading to dementia, this phenomenon seems unlikely. However, it would be premature to dismiss this possibility. Careful investigations should be performed on these subjects. Given that memories are only rendered inaccessible but not deleted in the brains of patients suffering from dementia, this phenomenon would open an intriguing field for future research on memory processing with the option to develop therapies to keep personal memories alive. Likewise, through a deeper understanding of the brain physiology determining TL, new ways of treating patients with schizophrenia and other mental illnesses might become available.

Representing a further challenge to the materialistic paradigm are the cases of the deaf-mute man (Schubert, 1808/1967) and Käthe. In these cases, there was no return of previously available faculties but, rather, the emergence of a qualitatively new bodily skill, namely speaking. To my knowledge, no materialistic theory of psychology or neurology to date could account convincingly for the latter examples. Given that these accounts are veridical, such cases would favor the second option: The traditional approach proposed by the ancient 
Greeks and Romans, Schubert, or Splittgerber, who assumed the human mind is more than a mere product of brain physiology, perhaps involving even a kind of "transcendental subject" or "hidden inner life" as du Prel and Happich proposed. This approach might also explain why TL seems so remarkably similar in (a) mentally healthy terminal patients, (b) mentally ill patients without noteworthy organic brain damage, and (c) mentally ill patients with organic brain damage of quite some degree and variety - an observation difficult reconcile with the materialistic model.

Yet, the traditional approach would bear difficulties for the development of new forms of therapies based on a deeper understanding of the brain physiology involved in TL. Rather, it suggests that during TL, brain physiology is of only minor importance. Then, the revival of consciousness and memories needs to be regarded as largely independent of the current state of the brain and its residual faculties. Therefore, the non-materialistic approach would justify reconsidering therapeutic approaches that acknowledge the possibility of "brain-free" consciousness. It also would justify reconsidering - if only as a working hypothesis - the possibility that the consciousness of one being can transfer to another and can cause mental disorder. Several sources assumed this approach (Crabtree, 1997; Fiore, 1987; Rogo, 1987; Wickland, 1924), including the Dalai Lama (Varela, 1997). These approaches could prove to be particularly valuable for mentally ill patients without noteworthy organic brain damage, such as those diagnosed with schizophrenia, dissociative identity disorder (formerly termed multiple personality disorder), and similar mental disorders. Perhaps it would be possible for at least some patients to reestablish mental health much earlier than a few hours before their death.

At any rate, TL should not be considered and explained as an isolated oddity associated with the deterioration of vital body functions. Rather, it seems likely that TL is interrelated with other reported experiences in near-death states that indicate paranormality, such as certain kinds of ELEs, or instances of unexplained body healing and apparently nonphysical veridical perception during NDEs. Additionally, such experiences might be related to other currently unresolved issues pertaining to human brain functioning during normal life. In the following paragraphs, I discuss some of these possible relationships.

With regards to unexplained body healing, it is noteworthy that several reports of such occurrences seem to have happened during 
NDEs. (For a recent case and references to other cases, see Sartori, Badham, \& Fenwick, 2006). It seems not unlikely that they are phenomenologically related to cases of unexplained emerging of previously unavailable body functions or skills during TL as recounted above. A report by Brayne, Lovelace, and Fenwick (2008) appears to support this view. A woman who was able only to look down to the floor for several years due to severe spinal fusion was struck with surprise as she noticed one day she could look out of her room window for the very first time. She died soon after. In another case, a man dying from lymphatic cancer, who had been unable to move his arm for over a year, moved his arm while he experienced a deathbed vision (Fenwick \& Fenwick, 2008). The "healing miracles" such as in Lourdes might also be considered a related phenomenon to TL and NDEs involving unexplained healing. According to Hans Gerloff (1959) and Ruth Cranston (1988), many of those who were healed at Lourdes reported that their healings were accompanied by an experience of bodily shock or sudden extreme pain and/or a sense of unawareness of what was going on in the physical world, of being transported beyond themselves, or of dying. Unfortunately, the intriguing field of unexplained body changes is as good as untouched today, despite its importance.

Correspondingly, some characteristics of the mental state during TL closely resemble those during NDEs. In fact, some incidents could be classified as TL experience as well as NDE (e.g., see the account of Driesch, 1951). Similar to the TL literature, the NDE literature starting with Moody (1975) brims with accounts involving enhanced mental clarity, elevated moods, spiritual wisdom, or transformation during and after NDEs. Moreover, of particular interest and well known to readers familiar with NDEs are apparently nonphysical veridical perceptions during times of severe brain malfunction or even standstill (e.g., Holden, 2007; Parnia, 2007). Could such reports be substantiated, they would support the non-materialistic approach towards understanding more intricate TL cases such as Käthe's.

As for the relation of the brain to the human mind during normal life, it seems advisable to recognize how little is known for certain even in regard to such seemingly simple faculties as recalling memories (Braude, 2006; Gauld, 2007).

In addition, authors have provided several accounts of severe brain injuries that were not followed by any impairment of mental faculties (Geley, 1920; Schiebeler, 1988; Surya, 1921). Even the drastic 
operation known as hemispherectomy - the removal of an entire brain hemisphere - often results only in specific impairments of motor skills and vision but has no apparent effect on personality and memory (Bell \& Karnosh, 1949; Choi, 2007). Leading surgeons in the field admit that they do not know how it is possible that patients with only half a brain can continue to live an almost normal life (Kenneally, 2006).

The research of British neurologist John Lorber might be related to these findings. After performing more than 600 scans on hydrocephalic patients, Lorber put forward the provocative question, "Is your brain really necessary?" (Lewin, 1980; Lorber, 1983). He found that about 30 individuals had a global IQ greater than 100 - despite cerebrospinal fluid instead of brain tissue filling $95 \%$ or more of their crania. Lorber loved citing the story of a student of mathematics whose global IQ was 126, his verbal IQ even reaching 143. In his case, "instead of the normal 4.5 centimeter thickness of brain tissue between the ventricles and the cortical surface, there was just a thin layer of mantle measuring a millimeter or so.... The boy has virtually no brain" (Lorber in Lewin, 1980, p.1232. For a recent noteworthy hydrocephalus case, see Feuillet, Dufour, \& Pelletier, 2007). Regrettably until now, such findings have not received appropriate attention and scientific follow-up.

In sum, there seems to be no simple 1:1 relationship between brain matter and the human mind. The whole affair is more complex. Taken together, there are indications that at least some features of the mind can function independently from firing neurons. Thus, proposing explanatory models for TL based on the second, non-materialistic assumption appears not so far-fetched as it may seem at first glance. At least, it should be regarded as a scientifically valid hypothesis that can be explored in future investigations.

\section{Outlook and Request for TLE Accounts}

As stated previously, the present state of TL research does not support the formulation of a definitive explanatory model for TL. Still, both approaches, the materialistic and the non-materialistic, hold the potential to provide important information for advancing new forms of therapies for mentally ill patients. If further studies would strengthen the case for the non-materialistic approach, this outcome would additionally have consequences for biology, medicine, psychology, philosophy - including the question of survival, and, last but not least, 
for palliative care and grief research. Therefore, the importance for researchers to conduct further studies on TL is obvious. The first step would be to collect well-documented case reports to achieve an overview of the phenomenology of TL. It is likely that especially health care providers working in the field of palliative medicine, hospices, or homes for people with mental disabilities have observed remarkable cases of TL but have so far not been willing or able to relate them to others, let alone to publish them. I strongly encourage them to do so, given the importance of the subject.

If you have experienced something remarkable around the time somebody died, including terminal lucidity, and are willing to share your experience, please feel free to send an account to me via postal mail or e-mail per the author information at the bottom of the first page of this article. I will not publish anything except anonymized and with written consent.

\section{Acknowledgements}

I thank Peter Fenwick, Bruce Greyson, Erlendur Haraldsson, Emily W. Kelly, and Hilary Lovelace for helpful comments, corrections, and inspiration.

\section{References}

Alvarado, C. (2006). Neglected near-death phenomena. Journal of Near-Death Studies, $24,131-151$.

Alvarado, C. (2007). Remarks on Ernesto Bozzano's La psiche domina la materia. Journal of Near-Death Studies, 25, 189-195.

Barbato, M., Blunden, C., Reid, K., Irwin, H., \& Rodriguez, P. (1999). Parapsychological phenomena near the time of death. Journal of Palliative Care, 15, 30-37.

Barrett, W. (1926). Death-bed visions. London, England: Methuen.

Becker, C. B. (1985). The pure land revisited: Sino-Japanese meditations and near-death experiences of the next world. Anabiosis - The Journal for Near-Death Studies, 4, 51-68.

Bell, E., \& Karnosh, L. J. (1949). Cerebral hemispherectomy. Journal of Neurosurgery, 6, $285-293$.

Betty, S. (2006). Are they hallucinations or are they real? The spirituality of deathbed and near-death visions. Omega, 53, 37-49.

Bozzano, E. (1906). Apparitions of deceased persons at death-beds. The Annals of Psychical Science, 3, 67-100.

Bozzano, E. (1982). Musica Trascendentale. Rome, Italy: Edizione Mediterranee. (Original work published 1943)

Braude, S. (2006). Memory without a trace. European Journal of Parapsychology, 21(2), 182-202. 
Brayne, S., Lovelace, H., \& Fenwick, P. (2008). End-of-life experiences and the dying process in a Gloustershire nursing home as reported by nurses and care assistants. American Journal of Hospice \& Palliative Medicine, 25, 195-206.

Brierre de Boismont, A. (2003). A history of dreams, visions, apparitions, ecstasy, magnetism and somnambulism. Whitefish, MT: Kessinger. (Original work published 1855)

Burdach, K. F. (1826). Vom Baue und Leben des Gehirns (Vol. 3). Leipzig, Germany: Dyk'sche Buchhandlung.

Callanan, M., \& Kelley, P. (1997). Final gifts. New York, NY: Bantam Books.

Choi, C. (2007). Strange but true: When half a brain is better than a whole one. Scientific American, May 24. Retrieved from http://www.sciam.com/article.cfm?id=strange-buttrue-when-half-brain-better-than-whole

Crabtree, A. (1997). Multiple man: Explorations in possession and multiple personality. Toronto, Canada: Sommerville House Books.

Cranston, R. (1988). The miracle of Lourdes. New York, NY: Doubleday.

Crookall, R. (1967). Events on the threshold of the after-life. Moradabad, India: Darshana International.

Driesch, H. (1951). Lebenserinnerungen. München, Germany and Basel, Switzerland: Ernst Reinhardt.

du Prel, C. (1976). The philosophy of mysticism (C. C. Massey, Trans.). New York, NY: Arno Press. (Original work published 1885)

du Prel, C. (1971). Die monistische Seelenlehre. In C. du Prel, Die Psyche und das Ewige. Pforzheim, Germany: Rudolf Fischer. (Original work published 1888)

du Prel, C. (2006). Die Mystik im Irrsinn. In C. du Prel, Studien zu den Geheimwissenschaften. Unser magisches Weltbild - Tatsachen und Probleme. Leipzig, Germany: Bohmeier. (Original work published 1889)

Fenwick, P., \& Fenwick, E. (2008). The art of dying. London, England, \& New York, NY: Continuum.

Fenwick, P., Lovelace, H., \& Brayne, S. (2007). End of life experiences and their implications for palliative care. International Journal of Environmental Studies, 64, 315-323.

Fenwick, P., Lovelace, H., \& Brayne, S. (2009). Comfort for the dying: Five year retrospective and one year prospective studies of end of life experiences. Archives of Gerontology and Geriatrics. In press, doi: 10.1016/j.archger.2009.10.004.

Feuillet, L., Dufour, H., \& Pelletier, J. (2007). Brain of a white-collar worker, Lancet, $370,262$.

Fiore, E. (1987). The unquiet dead: A psychologist treats spirit possession. Garden City, NY: Doubleday.

Flammarion, C. (1922). Death and its mystery: At the moment of death. London, England: T. Fisher Unwin.

Flournoy, T. (1903). Review of Mr. F. W. H. Myers's "Human personality and its survival of bodily death" (R. F. Cook, Trans.). Proceedings of the Society for Psychical Research, $18,42-52$.

Friedreich, J. B. (1839). Handbuch der allgemeinen Pathologie der psychischen Krankheiten. Erlangen, Germany: J. J. Palm und Ernst Enke.

Gauld, A. (2007). Memory. In E. F. Kelly, E. W. Kelly, A. Crabtree, A. Gauld, M. Grosso, \& B. Greyson, Irreducible mind: Toward a psychology for the $21^{\text {st }}$ century (pp. 241300). Lanham, MD: Rowman \& Littlefield.

Geley, G. (1920). From the unconscious to the conscious. Glasgow, Scotland: William Collins.

Gerloff, H. (1959). Die Heilungen von Lourdes im Lichte der Parapsychologie. BüdingenGettenbach, Germany: Welt und Wissen.

Giovetti, P. (1982). Near-death and deathbed experiences: An Italian survey. Theta, 10, 10-13. 
Giovetti, P. (1999). Visions of the dead. Death-bed visions and near-death experiences in Italy. Human Nature, 1, 38-41.

Grosso, M. (2004). Experiencing the next world now. New York, NY: Paraview Pocket Books.

Gurney, E., Myers, F. W. H., \& Podmore, F. (1886). Phantasms of the living. London, England: Trübner.

Holden, J. (2007). More things in heaven and earth: A response to "Near-death experiences with hallucinatory features." Journal of Near-Death Studies, 26, 33-42.

Holden, J. M., Greyson, B., \& James, D. (2009). The handbook of near-death experiences: Thirty years of investigation. Santa Barbara, CA: Praeger/ABC-CLIO.

Houran, J., \& Lange, R. (1997). Hallucinations that comfort: Contextual mediation of deathbed visions. Perceptual and Motor Skills, 84, 1491-1504.

Kelly, E. W., Greyson, B., Kelly, E. F. (2007). Unusual experiences near death and related phenomena. In E. F. Kelly, E. W. Kelly, A. Crabtree, A. Gauld, M. Grosso, \& B. Greyson, Irreducible mind: Toward a psychology for the $21^{\text {st }}$ century (pp. 367-421). Lanham, MD: Rowman \& Littlefield.

Kelly, E. F., Kelly, E. W., Crabtree, A., Gauld, A., Grosso, M., \& Greyson, B. (2007). Irreducible mind: Toward a psychology for the $21^{\text {st }}$ century. Lanham, MD: Rowman \& Littlefield.

Kenneally, C. (2006, July 3). The deepest cut. The New Yorker. Retrieved from http:// www.newyorker.com/archive/2006/07/03/060703fa_fact

Lewin, R. (1980). Is your brain really necessary? Science, 210, 1232-1234.

Lorber, J. (1983). Is your brain really necessary? In D. Voth (Ed.), Hydrocephalus in frühen Kindesalter: Fortschritte der Grundlagenforschung, Diagnostik und Therapie (pp. 2-14). Stuttgart, Germany: Enke Verlag.

Marshal, A. (1815). The morbid anatomy of the brain in mania and hydrophobia. London, England: Longman.

Martensen-Larsen, H. (ca. 1926). An der Pforte des Todes. Berlin, Germany: Furche.

Martensen-Larsen, H. (ca. 1927). Ein Schimmer durch den Vorhang. Berlin, Germany: Furche.

Martensen-Larsen, H. (ca. 1928). Am Gestade der Ewigkeit. Berlin, Germany: Furche.

Moody, R. (1975). Life after life. Covington, GA: Mockingbird Books.

Myers, F. W. H. (1892). The subliminal consciousness. Proceedings of the Society for Psychical Research, 7, 298-327.

O'Connor, D. (2003). Palliative care nurse's experiences of paranormal phenomena and their influence on nursing practice. Paper presented at the 2nd Global Making Sense of Dying and Death Inter-disciplinary Conference, Nov. 21-23, 2003, Paris, France. Retrieved from http://www.inter-disciplinary.net/mso/dd/dd2/D.O\%27Connor\% 20Paper.pdf

Osis, K. (1961). Deathbed observations by physicians and nurses. New York, NY: Parapsychological Foundation.

Osis, K., \& Haraldsson, E. (1977). Deathbed observations by physicians and nurses: A cross-cultural survey. Journal of the American Society for Psychical Research, 71, 237-259.

Osis, K., \& Haraldsson, E. (1997). At the hour of death ( $3^{\text {rd }}$ ed.). Norwalk, CT: Hastings House.

Parnia, S. (2007). Do reports of consciousness during cardiac arrest hold the key to discovering the nature of consciousness? Medical Hypotheses, 69, 933-937.

Perty, M. (1861). Die mystischen Erscheinungen der menschlichen Natur. Leipzig und Heidelberg, Germany: C. F. Winter'sche Verlagshandlung.

Rhine, L. (1963). Spontaneous physical effects and the psi process. Journal of Parapsychology, 27, 84-122.

Ring, K., \& Cooper, S. (1999). Mindsight. Palo Alto, CA: William James Center for Consciousness Studies. 
Ringger, P. (1958). Die Mystik im Irrsinn. Neue Wissenschaft, 8, 217-220.

Roesermueller, W. O. (1957). Um die Todesstunde. Nürnberg, Germany: Selbstverlag.

Rogo, D. S. (1987). The infinite boundary. New York, NY: Dodd, Mead.

Rogo, D. S. (2005a). A casebook of otherworldly music. San Antonio, TX: Anomalist Books. (Original work published 1970)

Rogo, D. S. (2005b). A psychic study of the music of the spheres. San Antonio, TX: Anomalist Books. (Original work published 1972)

Rush, B. (1812). Mental inquiries and observations upon diseases of the mind. Philadelphia, PA: Kimber \& Richardson.

Sartori, P., Badham, P., \& Fenwick, P. (2006). Prospectively studied near-death experience with corroborated out-of-body perceptions and unexplained healing. Journal of Near-Death Studies, 25, 69-84.

Schiebeler, W. (1988). Der Tod, die Brücke zu neuem Leben. Neuwied, Germany: Die Silberschnur.

Schubert, G. H. (1967). Ansichten von der Nachtseite der Naturwissenschaft. Darmstadt, Germany: Wissenschaftliche Buchgesellschaft. (Original work published 1808).

Schubert, G. H. (1968). Die Symbolik des Traumes. Heidelberg, Germany: Lambert Schneider. (Original work published 1814)

Splittgerber, F. (1881). Schlaf und Tod. Halle, Germany: Julius Fricke.

Splittgerber, F. (1884). Aus dem inneren Leben. Leipzig, Germany: Georg Böhme.

Stevenson, I. (1995). Six modern apparitional experiences. Journal of Scientific Exploration, 9, 351-366.

Surya, G. W. (1921). Der Tod kein Ende. Freiburg, Germany: Peter Hofmann.

Turetskaia, B. E., \& Romanenko, A. A. (1975). Agonal remission in the terminal stages of schizophrenia (M. H. Pertzoff, Trans.). Korsakov's Journal of Neuropathology and Psychiatry, 75, 559-562.

Varela, F. (1997). Sleeping, dreaming and dying. Boston, MA: Wisdom.

Wenk, G. L. (2003). Neuropathologic changes in Alzheimer's disease. Journal of Clinical Psychiatry, 64, Suppl. 9, 7-10.

Wickland, C. A. (1924). Thirty years among the dead. Los Angeles, CA: National Psychological Institute.

Wright, S. H. (1999). Paranormal contact with the dying: 14 contemporary death coincidences. Journal of the Society for Psychical Research, 63, 258-267. 